\title{
Evaluasi Penggunaan Gliserol dalam Pembuatan Preparat Telur Cacing Semipermanen
}

\author{
Shinta Asarina ${ }^{a}$, Nuni Haeruni ${ }^{\mathrm{a}}$ \\ ${ }^{\text {a }}$ Laboratorium Mikrobiologi dan Parasitologi, Fakultas Kedokteran \\ Universitas Padjadjaran, Bandung \\ E-mail : shinta.asarina@unpad.ac.id; nuni.haeruni@unpad.ac.id \\ Received: $24^{\text {nd }}$ January 2019; Revised: $18^{\text {th }}$ March 2019; Accepted: $19^{\text {th }}$ May 2019; \\ Available online: $14^{\text {th }}$ July 2019; Published regularly: July 2019
}

\begin{abstract}
Glycerol is one of the ingredients for preserving bacterial culture. Glycerol has hygroscopic properties so that it can absorb water molecules from the environment and prevent wet mount preparations. The use of glycerol in making semipermanent worm egg preparations for microscopic examination was evaluated in this study. This research was conducted at the Microbiology and Parasitology Laboratory of the Faculty of Medicine, Padjadjaran University, Bandung. From the results of the study it was found that worm egg preparations with the addition of glycerol can last longer than those without glycerol. This method can be recommended for making semipermanent worm egg preparations for the purpose of parasitological examination in the laboratory and student laboratory
\end{abstract}

Key Words: Gliserol ; Helminth ova ; Semipermanent

\begin{abstract}
Abstrak
Gliserol adalah salah satu bahan untuk mengawetkan kultur bakteri. Gliserol memiliki sifat higroskopis sehingga dapat menyerap molekul air dari lingkungan dan mencegah mengeringnya preparat wet mount Penggunaan gliserol dalam pembuatan preparat telur cacing semipermanen untuk pemeriksaan mikroskopik dievaluasi dalam penelitian ini. Penelitian ini dilakukan di Laboratorium Mikrobiologi dan Parasitologi Fakultas Kedokteran Universitas Padjajaran Bandung. Dari hasil penelitian didapatkan bahwa preparat telur cacing dengan penambahan glycerol dapat bertahan lebih lama dibandingkan dengan preparat tanpa gliserol. Metode ini dapat direkomendasikan untuk pembuatan preparat telur cacing semipermanen untuk keperluan pemeriksaan parasitologi di laboratorium maupun praktikum mahasiswa.
\end{abstract}

Kata Kunci: Gliserol ; Semipermanen ; Telur cacing.

\section{PENDAHULUAN}

Pemeriksaan mikroskopik dengan metode wet mount masih menjadi metode yang paling banyak dan sering digunakan di laboratorium untuk mengidentifikasi telur cacing dari spesimen feses. Metode ini mudah, tidak memakan waktu banyak dan murah, dan menghasilkan visualisasi langsung dari morfologi telur dan kista parasit. Kekurangan dari teknik ini adalah preparat yang dibuat menggunakan teknik ini tidak bertahan lama karena dapat mengering dalam waktu yang singkat, menyebabkan preparat tidak dapat dibaca. Untuk pemeriksaan lanjut harus dilakukan pembuatan preparat baru. Membuat ulang preparat cukup menghabiskan bahan reagen dan waktu (Parija, S.C. 1995) 
Gliserol telah lama digunakan pada pemeriksaan mikrobiologi untuk mengawetkan kultur bakteri. Gliserol memiliki sifat higroskopis sehingga dapat menyerap molekul air dari lingkungan dan mencegah mengeringnya preparat wet mount (khanna, V. 2014)

Penelitian ini berguna untuk menemukan suatu teknik preparasi wet mount dari sampel feses yang dapat bertahan lama dengan penambahan gliserol pada berbagai konsentrasi. Dengan penelitian ini, laboratorium dapat memproduksi preparat wet mount telur cacing khususnya dari sampel feses yang berkualitas untuk kegiatan praktikum mahasiswa, pelatihan bagi personil laboratorium, control positif untuk pelayanan pemeriksaan sampel feses sekaligus dapat memenuhi permintaan pelanggan yang ingin membeli preparat telur cacing dari laboratorium

\section{BAHAN DAN METODE}

Spesimen: sebanyak satu $\mathrm{ml}$ specimen feses yang telah diketahui mengandung telur cacing diisolasi telur cacingnya dengan menggunakan metode konsentrasi.

Preparasi Wet Mount: prepat aquades dan eosin dibuat secara terpisah dengan cara mencampurkan sejumlah kecil sampel feses dengan satu tetes aquades atau eosin $2 \%$ pada object glass dan letakkan cover glass di atas masing masing preparat.

Preparasi Gliserol Wet Mount: aquades-gliserol dan eosin-gliserol solution dibuat dengan mencampurkan aquades dan eosin $2 \%$ masing masing dengan gliserol konsentrasi 5, 10, 15, 20, 25 dan 30\% secara terpisah. Siapkan sejumlah kecil sampel feses di atas objek glass dan tambahkan 1 tetes aquades-gliserol atau eosingliserol kemudian letakkan cover glass di atas masing masing preparat. Beri entelan pada sisi-sisi cover glass

\section{HASIL DAN PEMBAHASAN}

Hasil pemeriksaan tingkat kebasahan preparat wet mount telur cacing setelah 6 minggu menunjukkan bahwa preparat aquades-gliserol dengan penambahan 0 - 15\% gliserol telah mengering di berbagai sisi, sedangkan preparat dengan konsentrasi 20, 25 dan 30\% gliserol masih bertahan tanpa mengering. Berbeda dengan preparat eosin-gliserol penambahan $0-30 \%$ gliserol yang mengering setelah 6 minggu (Tabel 1).

Tabel 1: Tingkat kebasahan preparat wet mount setelah 6 minggu.

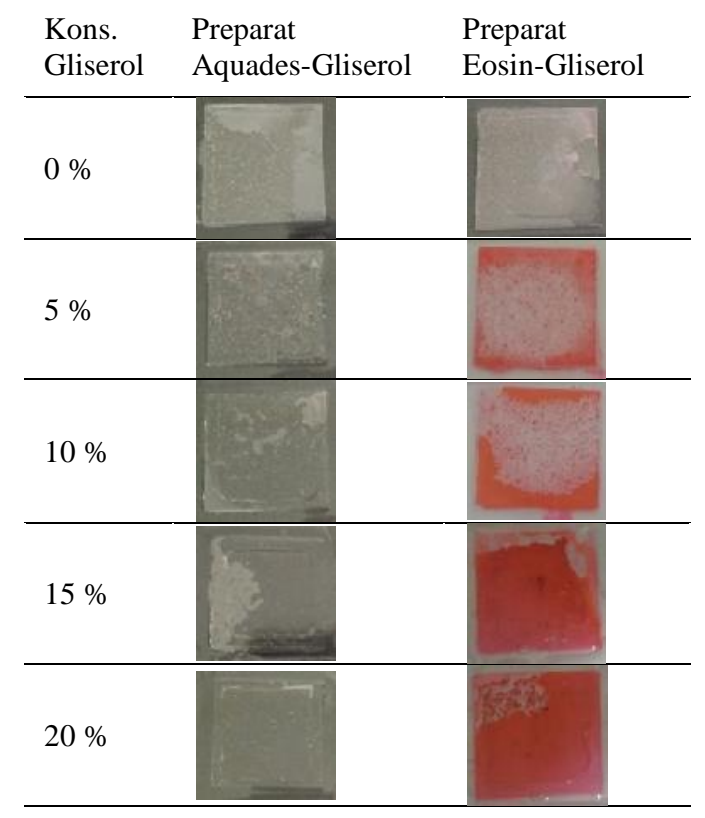

Copyright @ 2019, JPLP, e ISSN 2654-251X 


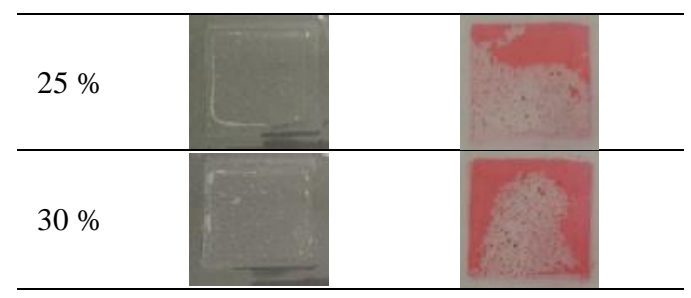

Preparat wet mount dengan penambahan gliserol di semua konsentrasi terbukti lebih tahan lama dan tidak kering dibandingkan preparat wet mount tanpa penambahan gliserol. Preparat aquades-gliserol lebih tahan lama dibandingkan preparat eosin-gliserol. (Neimeister, R. 1990)

Secara penampakan morfologi telur cacing di bawah mikroskop, preparat aquades-gliserol menunjukkan penampakkan preparat yang bersih dan mudah teramati. Berbeda dengan preparat eosingliserol yang terwarnai kemerahan sehingga lebih sulit teramati dan tidak nyaman di mata (Gambar 1).
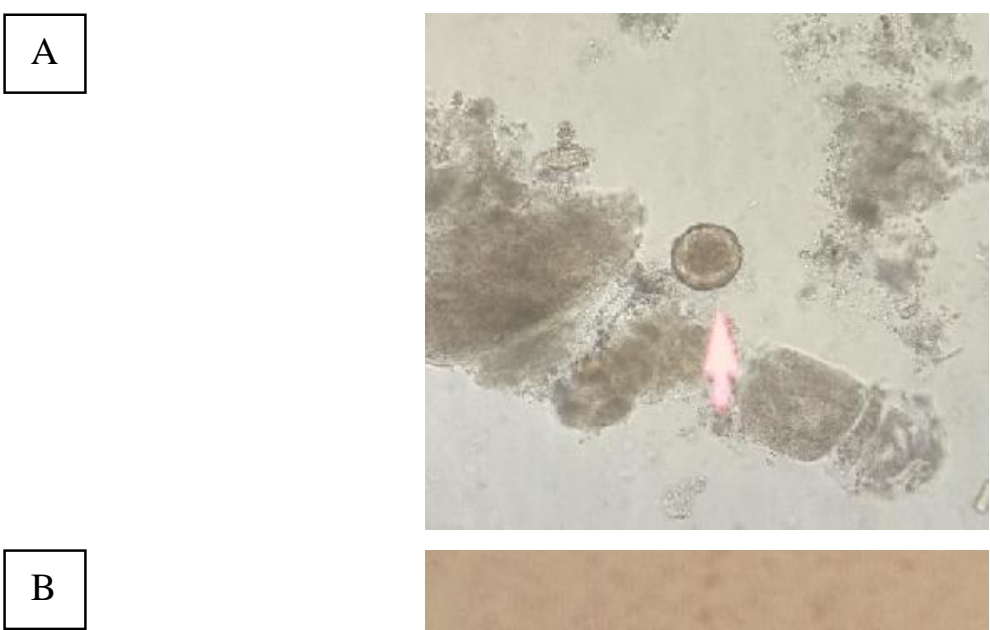

B

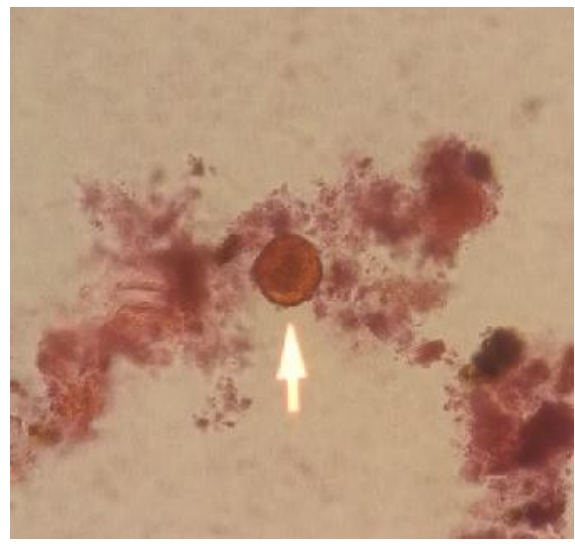

Gambar 1. A. Preparat Aquades - Gliserol; B. Preparat Eosin - Gliserol.

\section{KESIMPULAN}

Preparat telur cacing dengan penambahan gliserol menghasilkan preparat semi permanen yang bertahan lama dibandingkan dengan preparat tanpa penambahan gliserol. Preparat aquades-gliserol lebih bertahan lama dan menghasilkan penampakan morfologi yang lebih bersih dan mudah teramati dibandingkan dengan preparat eosin-gliserol. 
Preparat telur cacing semipermanen dengan penambahan gliserol merupakan metode yang sederhana, mudah, dan dapat bertahan lama sehingga memungkinkan untuk menghemat biaya pemeriksaan telur cacing.

\section{UCAPAN TERIMA KASIH}

Penelitian ini dibiayai oleh Riset Tenaga Kependidikan Universitas Padjadjaran (RTKU). Penulis berterimakasih kepada seluruh staf Laboratorium Mikrobiologi dan Parasitologi FK UNPAD yang telah memfasilitasi penelitian ini.

\section{DAFTAR PUSTAKA}

Khanna V., Tilak K., Rasheed S., Mukhopadhyay C. 2014. Identification and Preservation of Intestinal Parasites Using Methylene Blue Glicerol Mount: A New Approach to Stool Microscopy. Journal of Parasitology Research.

Neimeister R., Logan A.L., Egleton J.H., Kleger B. 1990. Evaluation of Direct Wet Mount Parasitological Examination of Preserved Fecal Specimens. Journal of Clinical Microbiology, May. 1990, p.10821084.

Parija S.C., Prabhakar P.K. 1995. Evaluation of Lacto-Phenol Cotton Blue for Wet Mount Preparation of Feces. Journal of Clinical Microbiology, Apr. 1995 p. 1019-1021.

Vagnesh R. et al. 2008. Wet mounting using iodine-glycerol provides a semi-permanent preparation for microscopic observation of faecal parasites. 